\title{
The Analysis of the Questions of Suncheon University's Students Majoring in Japanese in SRN (Self-Reflection Note)
}

\author{
Park Yoon-Ho \\ Suncheon University \\ \{pyh@sunchon.ac.kr\}
}

\begin{abstract}
This study introduces a method of learning using "SRN, SelfReflection Note“, which was conducted by Suncheon University's students majoring in Japanese. Also, the writer considered the questions raised by students and how to provide feedback during the SRN course.
\end{abstract}

Keywords: Self-Reflection Note, Japanese Language, Questions and Feedback

\section{INTRODUCTION}

The writer observed a typical classroom situation in the universities in Korea, which shows a cycle of process. When one enrolls in a major different with what have been wished for, one tends to avoid graduation, and instead, spends too many times in acquiring a foreign languagerelated certificate as well as overseas language training. This situation leads to a change in education point of view, from "How to Teach Easily," to "How to Get Students to Study on Their Own.". It then causes the emphasis on employment-related subjects, an increasing number of students doing part-time job during the school year, and finally, lack of basic knowledge, which will again lead to enrolling in a major different with one's wish. And this cycle goes on.

Yeom mi lan stated in his research that The crisis in the field of Japanese language education is getting worse. In middle and high school, (1) As part of the university's specialization project in 2014, (2) Recently in Japan related academia. In addition, efforts are being made to recognize the above problems and seek solutions. On April 15, 2017, at the symposium of the Japan Research Federation, Taiwan and other Japanese and humanities crises. Chung Ki Young (Busan University of Foreign Studies), Luo (The Department of Japanese Language at Taiwan University of Applied Sciences), Kazuhisa Toda (the Graduate School of Informatics, Nagoya University). And that the current crisis must be overcome through changes.[4] The subject of the study is the subject of the study of the Japanese language course of the college which is a majors. It is suggested that the class using 'SRN' is applicable to the Japanese language education,

I would like to suggest that 'SRN' can be one of the effective teaching methods for foreign language education.[5] 


\subsection{Research Method}

This research examined the effectiveness of Japanese education in Korean universities and aims to create a better educational environment by focusing on the development of teaching methods to practice in the field of lecture rooms. It introduces learning method using 'SRN' (Self-Reflection Note), which was conducted in Japanese education in Korea. The writer also considered how to provide feedback of questions raised by students in the course of SRN learning.

\section{RESULT AND DISCUSSION}

\subsection{Learning method of "SRN ( Self-Reflection Note )"}

\subsubsection{Development and Implementation of SRN}

Named the Self-Reflection Note, this learning method has been operated by the desired subject (professor) since 2015 with the supports of the Suncheon University

\subsubsection{Definition of SRN}

Learning tool that contains learners' understanding of learning, thinking, questions, and efforts. It provides self-reflective learning tools that enhance learners' self-directed learning skills and teaching assessment tools to observe learners.

'SRN' refers to observing and explaining one's own thoughts, feelings, and understandings. In other words, Study notes'. Students study weekly self-paced 'SRN'. It becomes a study for understanding and acquiring such as reviewing. And a sentence that expresses a concept or idea. In the case of Japanese and Japanese, you will be able to learn on your own, there is also a point. The instructor will check the students' academic status through the weekly 'SRN'. Interaction (feedback) efforts that identify the state and reflect it in the next lesson are very important.[7]

\subsubsection{Characteristics of SRN.}

The learners will write their own lessons. The learners will focus on the reflections. Professor provides feedback on understanding, concepts and learning.

\subsubsection{SRN Utilization Method}

Once every two weeks, students fill out and submit SRNs for the contents of study. Professor reviews the SRN, writes a review note, and uses it in class.

\subsubsection{Evaluation Method of SRN}

Evaluation methods are developed by professor according to subject's characteristics. There are research results of Park Sung-Hoon and Park Dong-guk (2015) using 'SRN'. However. It is about the major class. Especially, there is no study on foreign language education. The purpose of this study is to introduce 'SRN' and its effectiveness in Japanese language education. Japanese I Motivate learners to learn, and improve their ability to communicate It is a very important issue.[6]

In this trend, each university has a variety of teaching methods centered on the Center for Teaching and Learning Development (CTL) We are looking for and inducing change, but the number of participants has not increased significantly. This is because it is because the 
problem of the academic ability of the students is a problem rather than the recognition that it is the problem of the teaching method. Therefore, and to improve the teaching method of teaching guidance.[8]

\subsubsection{The Function of SRN}

Followings are the functions of SRN that can be elaborated from this research. (1) Function as an instrument of observation (2) Function as a tool for interactive feedback (3) Function as a learning tool (a tool in writing training) (4) Function as an assessment tool (5) Improving the ability to learn

\subsection{Examples of "SRN" for Japanese Language Education}

\subsubsection{Subjects and durations}

Subjects and durations of SRN in Sunheon University given as an example on this research is from September 2017 - December 2018, whith the following details:

1) 2nd semester of 2017 and 1st year of major (executed once), on the topic "Japanese Daily Conversation"

2) 1st semester of 2017-8 and 2nd year of major (executed twice), on the topic " Practicing Kanji in Japanese "

3) 2nd semester of 2017-8 and 2nd year of major (executed 2 times), on the topic "Japanese Animation"

Professor collects "SRN" paper in each class and categorizes it by the same content or type, and gives feedbacks on high frequency and important matters about the contents of the lecture, and that the student could not understand. Feedback is provided on the submission form (SRN paper) to students who specifically need to get feedback. Feedback to the entire class (questions of high frequency and matter most) is provided in a presentation. Lectures for more than 20 people are difficult. Since the distribution, collection, content analysis, creation and performance of feedback (individual, overall), personal consultation, and content organizing of the report paper are complicated, it should be conducted with care.

\subsubsection{Content of SRN}

There are 8 submissions of SRN papers in each semester. Questions written as a content of SRN, such as: (1) How far did you study this week? (2) How long have you spent time studying this subject this week? (3) Write more than one keyword from your self-study this week. (4) What is the most important thing you learned from this week's study? (5) If you don't understand anything about this week's study, write it down. (6) Write the points that the learners felt and realized during learning. (7) Write down your wishes for this week's class/environment/teacher, etc. (8) Write the most difficult part (or the core) of the Japanese language (such as grammar, words, interpretation, etc.) that you have attempted to resolve on your own this week. (Make sure to fill in.)

The key question is number 5 , in which the students can elaborate their answer on what they don't understand about the lesson. One of the questions from the student is "Which one is correct, writing “出来る” in Kanji (Chinese characters), or “できる” in Kana word? The answer for this question would be : The original form “出来る” is correct. However, in official texts, textbooks, newspapers and broadcasts, it is only in the case of nouns (出来上が 
り) written completely in Kanji. While In the case of verbs and adverbs(できる限り、できる だけ), it is the principle to write “できる” in KANA.

In this study, the problem-solving ability and the communication learning ability are strengthened. How to improve? How will you transition to learner-centered, creative and active education? In particular, I want to lay the groundwork for the new Japanese teaching methodology. The goal of research is to learners, demand Introduced 'SRN', a self-centered teaching and learning method, into Japanese language education and specifically business Japanese courses And discusses its effect.[5]

In this situation, lecturers not only give the answer itself, but also drawing up a schematic table and give more examples on the same category of question. Example: When used as an example of () , the following words are, in principle, written in KANA.

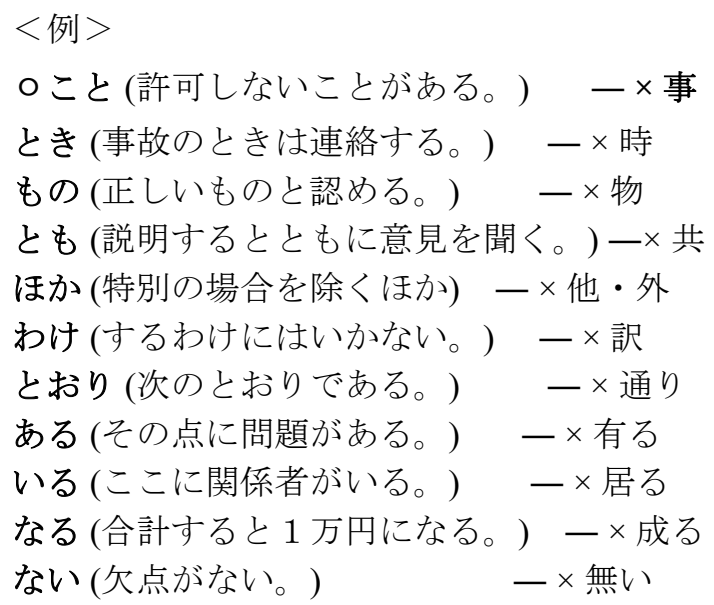

Based on Kyodo News, Reporter Handbook, 11th Edition of Newspaper Glossary:

1. Case for “出来”, written in Kanji when in form of Noun, such as:

上出来、出来合、出来上がり、出来上がる、出来、出来事、出来過ぎ、出来

損なう、出来高 (払い)、出来たて、出来值、出来のよい作品、出来、不出来、 出来具合(新聞協会 統一表記)

2. When in form of Verb and Adverb, basically written in Kana:

...すすことができる、できる限り、できるだけ、橋ができる、勉強がよくで

きる、用事ができる、理解できる、利用できる

\subsection{Example of "SRN" Question and Feedback}

\subsubsection{Questions from 'SRN'}

For the second purpose of this research, the writer thought about a questions ('SRN') from a Korean native speaker's Japanese learner and its teaching method. In particular, this research thinks about specific teaching methods of words or usage that correspond to Korean by putting together the types of synonyms that make up most of the questions. 
A basic word survey was based on the premise that this synonyms teaching method is applied for Korean native speakers who learn Japanese. And conducted the basic word survey using the "Self-Reflection Note" first. According to the survey, 100 significant words were found and 85 items were required by learners more than two times.

The details contained 60 significant terms for nouns, verbs, adjectives, and adverbs. And auxiliary verbs, investigations, conjunction and usage were 25 items. In particular, there were many cases where there were no Korean equivalent to Japanese and Chinese characters. Of course, there were many objections. As a future task, there remains the question of how to establish each significant language as an easy-to-understand language for native speakers of Korean and how to create conceptualized teaching methods.

\subsubsection{Examples of Feedback}

Example 1

For question 1 about synonym : How is “用意” different from Korean “準備’? There are 3 words in Japanese, but only 1 word in Korean. To explain this question, lecturer made following methods:

1. Pre-survey, is a method using a variety of materials such as professional books, papers, videos, sites, and YouTube.

pre-survey 1 [Usage] 準備・用意 - In the examples meaning to prepare in advance，「食事の 準備（用意）が整った]、「外出の準備（用意）をする」、「研究発表の準備（用意） をする」, etc. both can be used.

$\diamond 「$ 準備」 in sentences like「大会の準備をする」 does not mean just to prepare necessary materials (things), but includes the idea that you are managing an organization (event), and can be

considered more general

(encompassing).

$\diamond 「$ 用意」 as seen in「大地震にそなえて十分な用意をする」 and「当日は上履を御用 意ください」 puts the focus on collecting (preparing) the necessary goods (materials) in advance.

$\diamond$ Also the very similar 「支度」 is used for the specific action you are doing in order to prepare the necessary materials (things). 「支度金」 is the money used to buy the necessary goods (materials) > and「食事の支度をする」 means to collect the necessary goods and prepare food.

pre-survey2 -Between 準備 and 用意, they're both used for preparing in advance, but 用意 puts emphasis on preparing things in advance so they can be used when the time comes, so is used more when e.g. baking a cake in advance, and 準備 is used in a more general way, like preparations for an athletics carnival or something.準備 is also used in the expression 心の準 備はできている, which is used for mental preparedness in a similar way that 覚悟ができて いる is.・覚悟 is used when bracing oneself for something which is going to be unpleasant, or preparing for something that will be dangerous/difficult etc. • 支度 is particularly used in reference to meals e.g. preparing dinner (夕飯の支度をする), and preparing for the execution 
of something that's planned/done as a matter of course e.g. preparing for a trip (旅行の支度 をする) or preparing for school (学校へ行く支度をする). I believe 夕飯の用意をする is also used, so I think there's a bit of overlap.・備える is used for preparing for a disaster etc, or for preparing furniture or electrical appliances and whatnot so they can be used whenever they need to be.・できている can often mean something is in a prepared state ("ready", "completed" or "done" etc), and Xでできている means that something is made of X.

2. Drawing up a schematic table (screen feedback), easy and clear material tailored to the beginning and intermediate levels.

When the grade goes up, advanced grammar and vocabulary are naturally solved.

用意(ようい)する : The focus on collecting (preparing) the necessary goods (materials) in advance. 생각, 마음 씀

準備(じゅんび)する： More general 총체적, 갖추기

支度(したく)する : The specific action you are doing in order to prepare the necessary materials (things). 행동, 갖추기

\section{Example 2}

For the question : There are two ways of reading Japanese "何" and I don't know what it means.

Picture 3: explanation of 何

\begin{tabular}{|c|c|}
\hline なん & なに \\
\hline 무엇 (=what) & 무엇 (=what) \\
\hline $\begin{array}{l}\text { 次ぎにくる音が タ行、 } \\
\text { ダ行、ナ行の三行では } \\
\text { じまれば「なん」 }\end{array}$ & その他では「なに」 \\
\hline $\begin{array}{c}\text { 何と言っていいか } \\
\text { 分からない。 } \\
\text { 何でもいいよ。 }\end{array}$ & $\begin{array}{c}\text { 何か分からないことが } \\
\text { ありましたら。 } \\
\text { 何もおかしいことはない。 }\end{array}$ \\
\hline 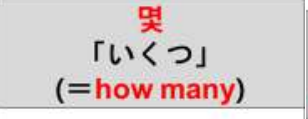 & $\begin{array}{c}\text { 무슨 } \\
\text { 「どんな (もの) 」（= } \\
\text { what kind of、 which) }\end{array}$ \\
\hline $\begin{array}{l}\text { 何色（ナンショク）、 } \\
\text { 何部（ナンブ）、何県 } \\
\text { (ナンケン) }\end{array}$ & $\begin{array}{l}\text { 何色（ナニイロ）、何部 } \\
\text { (ナニブ）、何県（ナニ } \\
\text { ケン） }\end{array}$ \\
\hline
\end{tabular}

\section{Example 3}

Question: What is the difference between 開く（あく）、開く(ひらく $)$ ?

Explanation: 開く(あく) is an intransitive verb. ドアが開く（どあがあく） The door opens. 開 $<(ひ ら く)$ is used as an intransitive verb and also used as a transitive one. ドアが開く（どあがひらく） The door opens. (intransitive) 彼はドアを開く（かれはど あをひらく) He opens the door. (transitive)

Picture 4: explanation for 開<

\begin{tabular}{|c|c|c|}
\hline $\begin{array}{l}\text { (저절로 - 自然に) } \\
\text { 열리다 } \\
\text { open by itself }\end{array}$ & $\begin{array}{c}\text { (닫혔던 것, 업무, 일 - 閉める, 睘むもの. } \\
\text { 業務, 仕事) 열리다 /(시작, 창시 - 創始)열다 } \\
\text { open up what has been done }\end{array}$ & $\begin{array}{l}\text { (쪽, 쏙, 막힘 없이=塞 } \\
\text { がれることな } \\
\text { <)열리다 wide open }\end{array}$ \\
\hline 開(あ)< & 開(ひら)< & 開(ひら)ける \\
\hline
\end{tabular}




\section{Example 4}

Question: What is the difference between ぐらい、ほど? Lecturer explained by using YouTube and Yahoo Japan Chiebukuro. Picture 5. explanation from YouTube Channel:

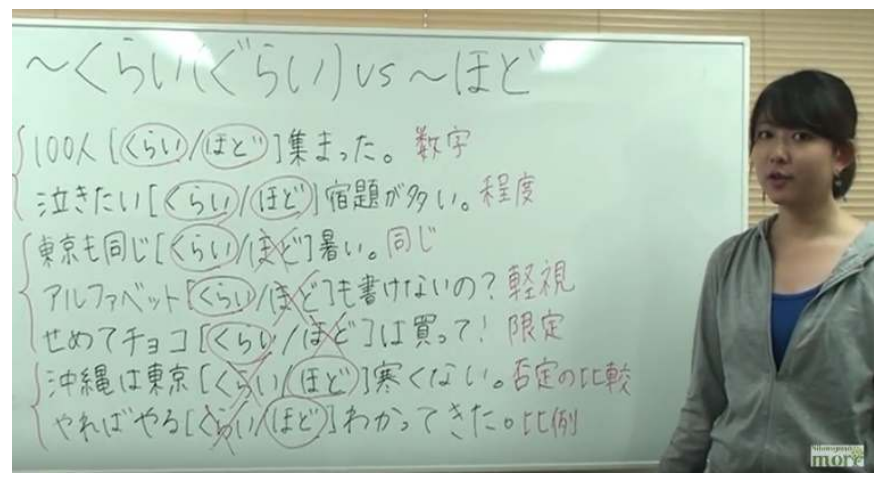

Nihongo No Mori

Picture 6. SRN feedback screen

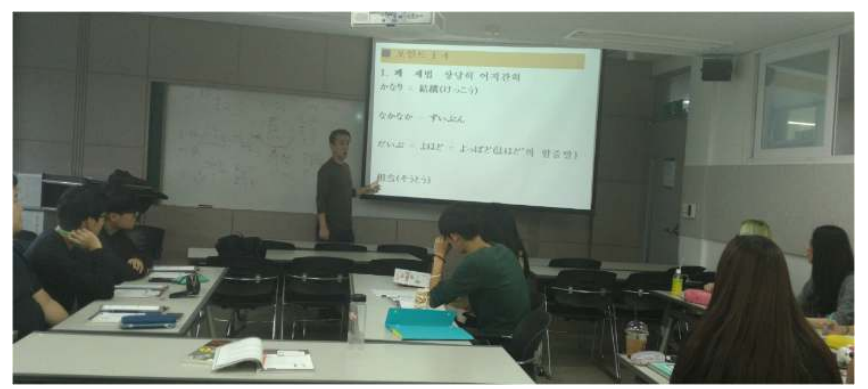

\section{CONCLUSIONS}

This research concluded the effects and suggestions for 'SRN' classes, which focusing on eliciting changes in students' attitudes toward subjects. The application of SRN Learning Method gives some effects, such as: 1) Self-Oriented Learning Guidance; 2) Induction to private consultation; 3) The improvement of one's basic education; 4) Overcoming the difficulties of learning Japanese. Meanwhile, feedback-oriented lecture can give effects as following: 1) Interest in the learner's related subjects and motivation to learning; 2) The formation of a foundation to achieve the level of knowledge required for a major; 3) Focus on students who are passive in learning; 4) Improve the proficiency of students at higher levels. In order to develop of teaching method of synonyms (more than drawing up schematic table), For future tasks, researchers and lecturers need to create a method of teaching and also develop conceptualized teaching, in which synonyms are settled in a language that is easily understood. 


\section{REFERENCES}

[1] Yoshiyuki Morita (1988) The synonymous expression in Japanese (森田良行(1988) 『日本語の類意表現』)

[2] Won-mi Kim(2013)Pedagogical Vocabulary Investigation for the Purpose of Diagramming of Japanese Synonyms as a Learning Tool

[3] Kyodo News, Reporter Handbook, 11th Edition of Newspaper Glossary

[4] 정동섭, “교양 스페인어 수업의 플립드 러닝(Flipped Learning) 수업모형 제안,” 스페인라틴아메리카연구, vol. 8, no. 1, pp. 127-150, 2015.

[5] 房極哲, "SRN (Self Reflection Note) 을 활용한 전공 일본어교육-비즈니스 일본어 수업 사례를 중심으로," 한국일본어교육학회 학술발표논문집, pp. 29-42, 2017.

[6] 박성훈 - 박동국(2015) - 교수법가이드 Self Reflection Note(SRN) 순천대학교 교양기초교육원 교수학습개발센터방극철(2014) ‘韓国における日本語教育の現状 と課題”宮崎大学 Japanese language Educational Forum pp.1 19

[7] 조대하(2017)「PBL 기반 일본어 ‘교과교재연구 및 지도법’ 수업사례 연구」 일본어교육연구· $38,149 \cdot 166$

[8] 박성훈 - 박동국(2015)「대학에서 교양 일본어(제 2 외국어) 교육 개선을 위한 실천적 제안」 日本語教育 $74 \mathrm{pp} .1526$ 